\title{
Medium, Vector, and Connector: Fog and the Maintenance of Ecosystems
}

\author{
Kathleen C. Weathers, ${ }^{1 *}$ Alexandra G. Ponette-González, ${ }^{2}$ and \\ Todd E. Dawson ${ }^{3}$
}

\begin{abstract}
${ }^{1}$ Cary Institute of Ecosystem Studies, Box AB, Millbrook, New York 12545, USA; ${ }^{2}$ Department of Geography and the Environment, University of North Texas, 1155 Union Circle \#305279, Denton, Texas 76203, USA; ${ }^{3}$ Departments of Integrative Biology and Environmental Science, Policy \& Management, University of California, Berkeley, Berkeley, California 94720, USA
\end{abstract}

\begin{abstract}
Fog and low-lying cloud (fog) play a significant role in the maintenance of ecosystems, from desert to alpine and from coastal to inland systems. Our central thesis is that fog provides ecosystems with critical water and nutrient subsidies, and also delivers pollutants, that often control ecosystem function. Fog is a medium, vector, and connector. In this mini-review, we synthesize recent research advances that reveal the diverse ways that fog shapes ecosystem processes. Crown wetting, elemental deposition, and light scattering and absorption are fundamental mechanisms by which fog has been shown to influence water fluxes, productivity, and decomposition in hyper-arid to ever-wet regions. These impacts are ultimately
\end{abstract}

\section{HighLIGHTS}

- Fog subsidizes ecosystems and modulates their light climate

Received 16 November 2018; accepted 7 April 2019;

published online 6 May 2019

Electronic supplementary material: The online version of this article (https://doi.org/10.1007/s10021-019-00388-4) contains supplementary material, which is available to authorized users.

Author's contributions We make no distinction in effort or contribution between the first and second authors. KCW and TED conceived of the review; AGPG synthesized and analyzed the data and created the figures with KCW; KCW and AGPG wrote the paper and all authors edited the paper.

*Corresponding author; e-mail: weathersk@caryinstitute.org mediated by the structure and composition of biological systems that allow fog capture and utilization of resource subsidies. Climate change, and changes in land use, ocean circulation, and atmospheric pollution are simultaneously altering the nature of fog itself, and the architecture of the ecosystems adapted to capture it. The coupling between atmosphere and biosphere in fog-enshrouded areas raises new questions about past and future fog-dominated ecosystems, and their maintenance and diversity, in the face of global change.

Key words: cloud; water; elements; light; productivity; decomposition; ocean-land interactions; microbes; global change.
- Fog influences ecosystem processes: water flux, productivity, decomposition, and elemental cycling

- Fog is dynamic, encompassing and connecting ocean, atmosphere, and terrestrial system interactions

\section{INTRODUCTION}

Fog and low-lying cloud (hereafter fog) immerse and influence ecosystems across the globe (Weathers 1999). Ground fogs are common in valley bottoms and envelop low-lying systems, advection fogs inundate coastal forests and hyperarid deserts along nearshore-coastal upwelling zones, and mountain-mists are a constant occur- 
rence in tropical and temperate montane cloud forests in the new and old worlds alike. The small horizontally driven droplets of liquid water that enshroud and impact animal and plant surfaces and deliver water and nutrients have long been considered to be fundamentally important to these fogdominated ecosystems (for example, Kerfoot 1968), but how does fog contribute to ecosystem function (Weathers 1999)?

Although the answer to this question is still incomplete, scientific interest in and inquiries into fog date back centuries. Perhaps most notable in regard to fog and pollution is nineteenth century London, when smoke pollution from widespread, coal-based heating and coal-powered industries coupled with cool temperatures contributed to high fog-or more appropriately named "smog"-frequency, raising concerns about the public health of urban residents (Weathers and Lovett 1998; Thornes and Metherell 2003). Studies examining fog chemistry and fog-vegetation interactions followed not long after, and by the early to mid-1900s ecologists and geographers had begun to estimate the amount of fog drip under individual trees or across wide areas of the landscape using simple observations and rudimentary collectors (for example, Marloth 1903, 1905; Means 1927). Along the U.S. California coast, scientists aptly noted the influence of tree height and topography on fog water deposition to soil as well as the spatial overlap between redwood communities and the fog belt (Oberlander 1956; Parsons 1960). Meanwhile, investigations of air pollution impact on forest vegetation in North America and Europe prompted research on the chemistry of fog and its potential role in biogeochemical cycling (for example, Schlesinger and Reiners 1974; Dollard and others 1983; Munger and others 1983; Fuzzi and others 1985; Schemenauer 1986; Weathers and others 1986). At this time, fog was also garnering attention among tropical ecologists, some of whom suggested that fog was possibly the most salient factor affecting the structure and function of highelevation tropical forests (Grubb and Whitmore 1966; Baynton 1968).

Subsequent decades witnessed increased efforts to assess the relative significance of fog as a hydrological input to ecosystems (for example, Ingraham and Matthews 1988, 1995; Cavelier and Goldstein 1989; Bruijnzeel and Proctor 1995; Dawson 1998; Ewing and others 2009; Lehnert and others 2018), as a vector of nutrient and pollutant deposition (for example, Weathers and others 1988, Weathers and Likens 1997; Collett and others 1998, Heath and Huebert 1999; Weathers and others 2000; Baumgardner and others 2003; Ponette-González and others 2010a; Desyaterik and others 2013; Templer and others 2015; WeissPenzias and others 2016), and as a water source for plants, plant communities, and even beetles, during otherwise rainless periods (for example, Seely 1979; Dawson 1998; Burgess and Dawson 2004; Corbin and others 2005; Seely and others 2005; Ewing and others 2009; Fischer and others 2009; Limm and others 2009; Simonin and others 2009; Matimati and others 2012; Warren-Rhodes and others 2013; Baguskas and others 2014).

Fog has since been shown to modulate several plant (for example, Burgess and Dawson 2004; DelVal and others 2006; Gutiérrez and others 2008; Goldsmith and others 2013; Alvarado-Barrientos and others 2014; Gotsch and others 2014) and, less frequently, ecosystem functions (Ewing and others 2009; Carbone and others 2013; Templer and others 2015; Fischer and others 2016). Here, we provide a framework for conceptualizing the mechanisms for fog-ecosystem interactions. Our central thesis is that water, elemental, and biological inputs from fog can subsidize inputs from rainfall—or represent the entire annual hydrologic, labile elemental, and/or biological flux to a system. Further, fog modulates heat, water, and radiative interactions between atmosphere and terrestrial systems. Much of the literature points to fog's direct hydrological inputs as most important in controlling ecosystem processes; here, we suggest that energy and hydrological modulation-meaning an impact that can improve both overall water balance from primary inputs of water and secondary benefits to the organisms that receive the inputs-are likely to be equally important. Perhaps the most important influence fog has on terrestrial ecosystems is how it impacts the strength and manner of coupling between the atmosphere, vegetation, and the soil processes known to drive ecosystem functions, such as water flux, productivity (Nyaga and others 2015; Templer and others 2015), element cycling, and decomposition (for example, Jacobson and others 2015; Figure 1).

We explore our conceptual framework by first synthesizing studies on the role of fog as a medium and vector. We then review recent research on the diverse ways that fog impacts processes from plants to ecosystems. We conclude by identifying frontiers where research is now needed to better understand fog's role as a connector among atmosphericocean-terrestrial systems. Finally, we speculate on how global change will alter the availability, nature, or capture of this ephemeral resource and, in turn, fog-ecosystem interactions. 


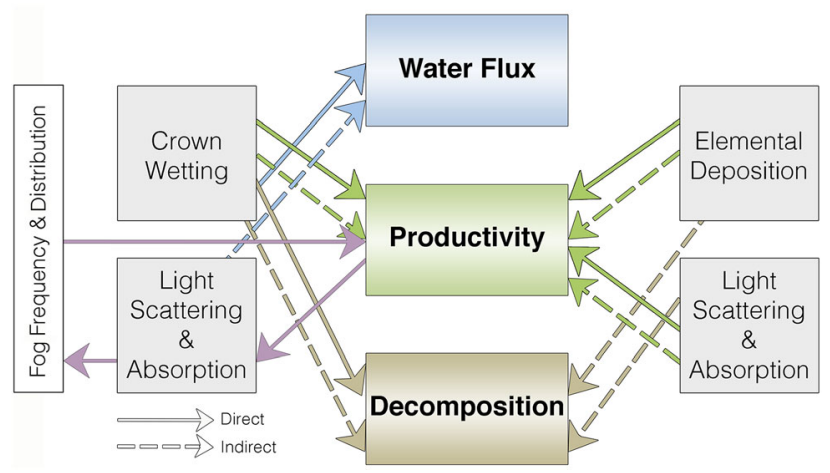

Figure 1. Mechanisms—crown wetting, elemental deposition, light scattering, and absorption-by which fog can directly (solid arrows) and indirectly (dashed arrows) influence major ecosystem functions, including water flux, productivity, and decomposition. Purple arrows indicate feedback effects (Color figure online).

\section{Fog as Medium and Vector}

Fog serves as a medium and vector, delivering, supplying, and regulating the flow of critical limiting resources-water, elements, and light-to ecosystems. Fog influences the "top" (forest canopy or tree crowns) and "bottom" (soils and rhizosphere) of ecosystems when droplets advected by wind envelop and collide with plant surfaces, evaporate back to the atmosphere, are directly absorbed into tissues or areal soils or, alternatively, coalesce and fall to the ground.

\section{Water}

Estimates of fog water inputs to the top of vegetation canopies vary widely within and across ecosystem types due to differences in climatic and meteorological factors as well as measurement methods (Dollard and Unsworth 1983), ranging from $11 \%$ to $83 \%$ of total (rain + fog) annual precipitation (Figure 2; Supplemental Material). The relative importance of fog increases as water becomes more limiting to plant performance and growth as well as to critical ecosystem functions. At subtropical sites with extreme aridity, including northern Chile, western South Africa, and the Namib Desert, fog moisture comprises a median of $83 \%$ of the total above-canopy water input (Figure 2), although inputs may display high interannual variability due to large-scale climatic oscillations (ENSO; del Río and others 2018). There are also many ecosystems, including those with a Mediterranean climate, or those located at the edge of the tropics, where fog represents either the primary source, for example, about 100\% (Hildebrandt and others 2007; Lehnert and others 2018), or a significant proportion, from approximately 2535\% (Dawson 1998), of the above-canopy dryseason water input.

Measurements of below-canopy fog fluxes show that the amount of fog water deposited to soils is strongly affected not only by climatic and meteorological conditions but also by vegetation and three-dimensional canopy structure (Nadkarni and Sumera 2004; Ewing and others 2009; PonetteGonzález and others 2010b, 2014; Chung and others 2017). As fog water falls from the canopy toward the soil surface, leaves, branches, mosses, and epiphytes, intercept, retain, and even absorb fog droplets. As a result, the soil of ecosystems with a high degree of vertical stratification (vegetation layering), such as tropical and temperate montane forests, may receive less than half the inputs deposited to the top of the ecosystem (Figure 2). In subtropical forests and woodlands characterized by less vertical complexity, such as those found on the Island of Madeira in Portugal, atmosphere-to-canopy inputs and canopy-to-soil fog fluxes can be of similar magnitude (Prada and others 2009). For comparison, in tropical and temperate montane and lowland forest, throughfall is about $80 \%$, whereas stemflow is $2-6 \%$ of rainfall (PonetteGonzález and others 2016). Leaf- and crown-scale physiological research across a wide range of tropical (Goldsmith and others 2013), temperate (Berry and others 2014; Emery 2016; Baguskas and others 2017), and desert (Hill and others 2015; Yan and others 2015) plants demonstrates that direct absorption of water into leaves and stems is more widespread than botanists originally had thought and has physiological impacts, such as improved water status, that until recently were not appreciated. 


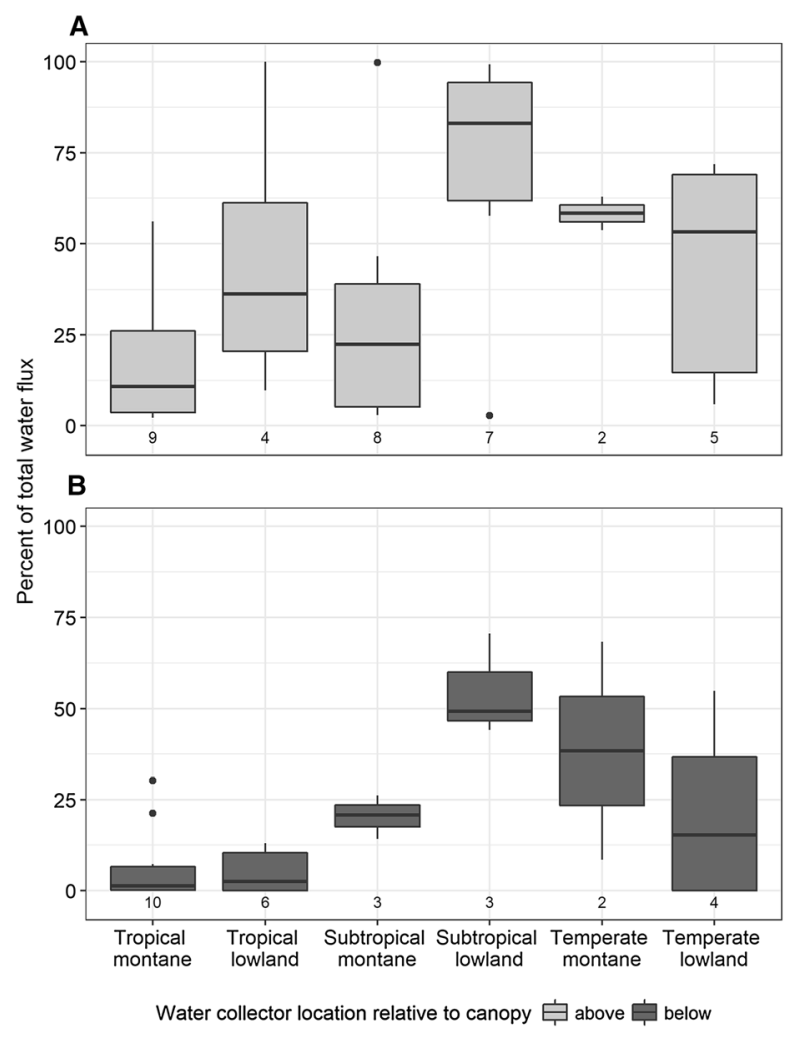

Figure 2. Fog water inputs to montane $(\geq 1000 \mathrm{~m})$ and lowland $(<1000 \mathrm{~m})$ forest, woodland, grassland, and desert ecosystems in tropical $\left(0-23.5^{\circ}\right)$, subtropical (23.5$\left.35^{\circ}\right)$, and temperate $\left(35-66^{\circ}\right)$ regions where fog was measured for nine months or more. A Fog water fluxes to artificial collectors installed above vegetation canopies or in clearings and displayed as a percentage of total annual water input (rainfall + fog precipitation). B Fog water fluxes to forest soils as a percentage of total annual water input (rainfall + fog drip). Boxplots represent interquartile ranges $\left(25^{\text {th }}\right.$ and $75^{\text {th }}$ percentiles $)$, horizontal bars denote median values, and whiskers sample minimum and maximum values. See Supplemental Material for a list of studies included.

\section{Elements}

Along with water, fog transports nutrients and pollutants incorporated into droplets during fog formation and/or washout (that is, the collision of particles with moving fog droplets). Sampling conducted around the world shows that chemical concentrations are often higher in fog as compared with rain (Weathers and others 1988; Figure 3) often due to the smaller size (Bator and Collett 1997) and lower liquid water content of fog droplets (Lovett and others 1982; Anderson and others
1999). In southern Chile (Weathers and Likens 1997; Weathers and others 2000), Hawai'i (Carrillo and others 2002), and Japan (Aikawa and others 2006) concentrations of nitrate $\left(\mathrm{NO}_{3}{ }^{-}\right)$, ammonium $\left(\mathrm{NH}_{4}{ }^{+}\right)$, and calcium $\left(\mathrm{Ca}^{2+}\right)$ in fog have been shown to be enhanced by more than 50 -fold over those in rainwater. Further, Weathers and others (2000) have documented high concentrations of labile phosphorus (as phosphate) in coastal fog. Fog water also has distinct regional signatures that reflect the origin and trajectory of air masses (Gioda and others 2011, 2013). In coastal, near-coastal, and marine environments, such as Puerto Rico (Weathers and others 1988; Asbury and others 1994), Chiloé Island (Weathers and others 2000; Weathers Unpublished Data), and Hawai'i (Carrillo and others 2002), sea salt ions (sodium $\left(\mathrm{Na}^{+}\right)$and chloride $\left.\left(\mathrm{Cl}^{-}\right)\right)$are the most prevalent in fog water, whereas in urban and industrial environments in the USA and Europe fog droplets often have low $\mathrm{pH}$ due to sulfuric and nitric acids (for example, Waldman and others 1982; Weathers and others 1986; Thalmann and others 2002; Aleksic and others 2009). In agricultural and arid areas, such as in southern China (Liu and others 2005) and Congo (Lacaux and others 1992), biomass burning and dust emissions contribute to high concentrations of $\mathrm{NH}_{4}^{+}$, potassium $\left(\mathrm{K}^{+}\right), \mathrm{Ca}^{2+}$, and magnesium $\left(\mathrm{Mg}^{2+}\right)$ in fog.

That fog-borne chemistry is often more concentrated than rain means that fog can be a significant pathway of atmospheric deposition to ecosystems. For example, in the Appalachian Mountains, where fog frequencies are high during the summer season (June-September), fog is estimated to contribute $80-90 \%, 70-87 \%$, and $90-95 \%$ of total (wet + dry + fog) $\mathrm{SO}_{4}{ }^{2-}, \mathrm{H}^{+}$, and $\mathrm{NH}_{4}{ }^{+}$deposition, respectively (Baumgardner and others 2003). Even when fog water inputs are quantitatively insignificant compared to rain, fog can be a major vector of nutrient and pollutant inputs to ecosystems (Weathers and others 2000; Ewing and others 2009; Nyaga and others 2015; Vandecar and others 2015) - a little fog can go a long way. The fate of these chemical inputs ultimately depends on the form in which the element is deposited as well as biological demand. Biologically active ions, such as $\mathrm{NH}_{4}{ }^{+}$, may be taken up by or leached from plant canopies (Templer and others 2015) depending on nutrient status, while biologically conservative ions including $\mathrm{SO}_{4}{ }^{2-}$ and $\mathrm{Na}^{+}$are typically washed from the canopy and transferred to soils in throughfall (Weathers and others 2006). 


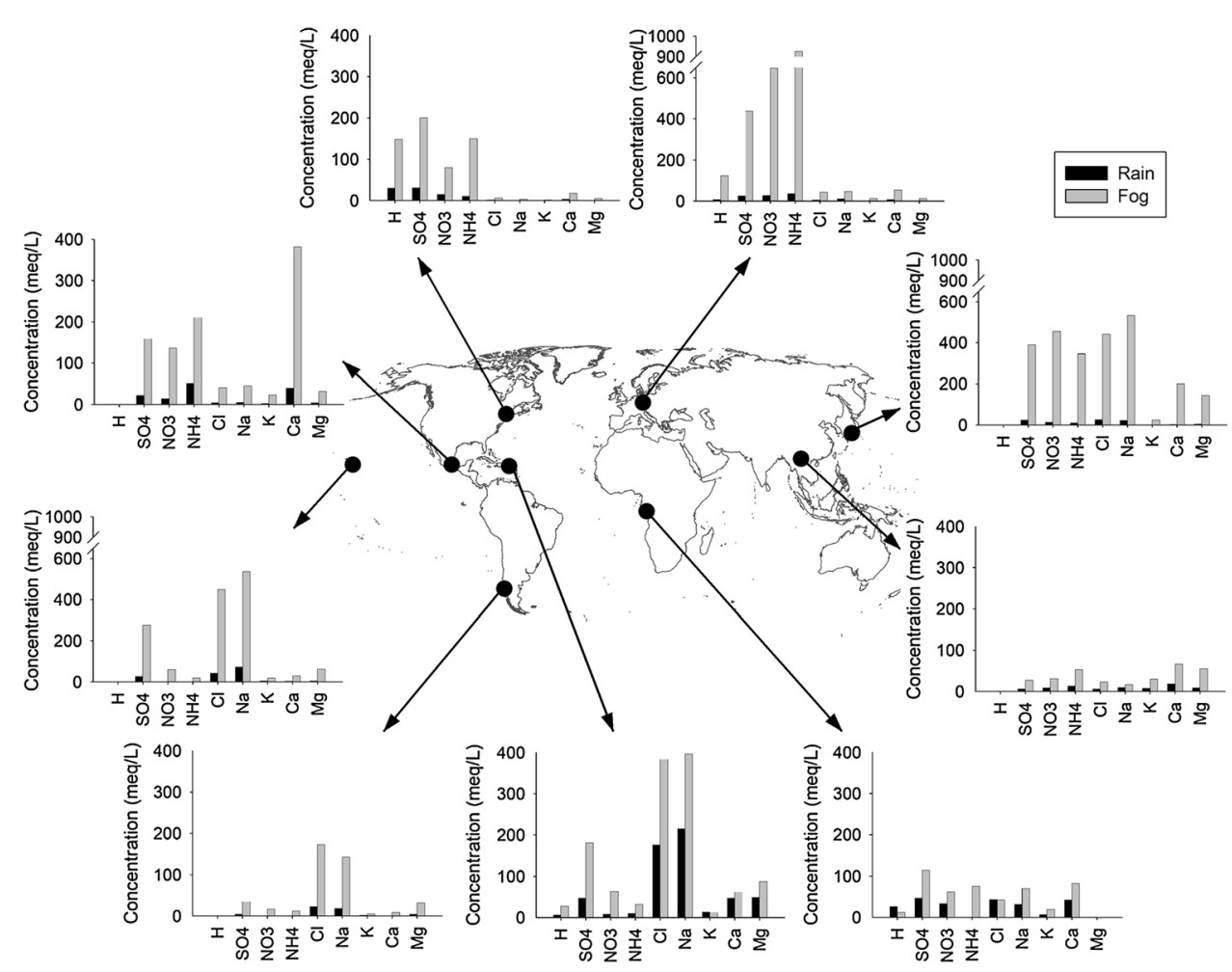

Figure 3. Chemical concentrations ( $\mu \mathrm{eq} / \mathrm{L}$ ) of paired rain and fog water samples collected at sites influenced by natural (volcanic, marine, dust) and anthropogenic (agricultural, industrial, and urban) emissions sources. From top left clockwise, data from: Báez and others (1997), Aleksic and others (2009), Thalmann and others (2002), Liu and others (2005), Aikawa and others (2006), Lacaux and others (1992), Asbury and others (1994), Weathers (Unpublished Data), Carillo and others (2002).

\section{Light}

Fog presence also alters the light climate of ecosystems. Under foggy conditions, total shortwave radiation can be reduced by as much as $75 \%$ (Ritter and others 2009). Because of the resultant reduction in energy at the surface, the presence of fog also decreases upward longwave fluxes (Klemm and others 2006). Downwelling longwave radiation, however, can be enhanced by up to $15 \%$ (Brant and others Unpublished Data). In addition, fog increases the proportion of diffuse to direct radiation, modifying the intensity, duration, and quality of light reaching vegetation canopies. Enhanced diffuse radiation reduces peaks in maximum sunlight and dampens temporal variations in the supply of photosynthetically active radiation (PAR; Johnson and Smith 2006), but this also leads to greater PAR penetration into deep forest canopies (Still and others 2009) that in turn can enhance photosynthesis of lower canopy leaves and understory plants (Gu and others 2003; Santiago and Dawson 2014). During fog immersion, changes in the amount of blue and red light as well as spectral band ratios have also been measured (Reinhardt and others 2010).

\section{Fog and the Maintenance of Ecosystems}

How does fog impact-contribute to or detract from-the maintenance of ecosystems? On the one hand, fog resource subsidies can extend or sustain ecosystem function where processes would otherwise slow or cease due to water deficits or low/lack of elemental inputs (Jacobson and others 2015). On the other hand, ecosystem processes may be slowed or even impaired where fog inputs promote water saturation or deliver excess pollutants or toxic elements (Weathers and others 1986; Lawson and others 2003; Weiss-Penzias and others 2012). What is clear is that fog modulates the manner and magnitude of the coupling between the atmosphere, vegetation, and soils. In the case of animals, some of the best-known examples are from the Namib Desert, where beetles and microbial communities have adapted in charismatic ways to capture fog water for consumption (Seely 1979; Parker and Lawrence 2001; Nørgaard and Dacke 
2010; Warren-Rhodes and others 2013): some of the most notable are Darkling beetle hand-standing and burm-building techniques to enhance fog water capture in this hyper-arid desert (for example, Nørgaard and Dacke 2010).

\section{Crown Wetting}

Looking up from the canopy, fog events that do not produce throughfall sustain hydrological connections between tree crowns and the atmosphere. Early fog researchers suggested that fogginess and associated crown wetting could reduce evapotranspiration, and, in turn, carbon (Grubb and Whitmore 1966) or nutrient uptake (Odum and Pigeon 1970) by trees. However, contrary to these hypotheses, recent work in forested ecosystems indicates that crown wetting events can enhance leaf water potential above that expected from soil water availability alone, functionally decoupling tree canopies from soil water supplies (Burgess and Dawson 2004; Simonin and others 2009; Gotsch and others 2014, Dawson and Goldsmith 2018; Berry and others 2018). Further, crown wetting suppresses transpiration and improves leaf hydration (Alvarado-Barrientos and others 2014), extending the time available for foliar fog water (and nutrient) uptake (Limm and others 2009; Goldsmith and others 2013). Thus, fog subsidies may not just allow, but actually enhance, aboveand below-ground productivity and carbon sequestration during water-limited periods (Williams and others 2008; Ritter and others 2009; Simonin and others 2009; Carbone and others 2013; Eller and others 2013; Emery 2016).

Looking down through the forest canopy, fog droplets that drip from trees or run down stems increase surface soil moisture (Li and others 2018; Poca and others 2018), providing water for plant uptake and transpiration (Dawson 1998; Ewing and others 2009). Depending on overall precipitation regime and soil water content, added soil moisture may suppress (Chang and others 2008) or stimulate (Carbone and others 2011, 2013) soil respiration. These water inputs are often not evenly distributed over horizontal space, as is the case in landscapes where structural (for example, forestgrass boundaries) and functional (for example, slopes) edges lead to elevated fog inputs (Weathers and others 1992, 1995, 2000). In coastal California, Ewing and others (2009) documented an exponential decline in fog drip along a redwood forest edge-to-interior gradient that was mirrored by similar declines in soil moisture, leaf area, litterfall, fine root production, and soil organic matter accumulation. In hyper-arid deserts such as the Namib, fog inputs to soil are critical to the landscape-scale sustenance of hypolithic cyanobacterial communities (Warren-Rhodes and others 2013) and to decomposition dynamics (Jacobson and others 2015; Evans and others 2018). Jacobson and others (2015) found that within minutes of wetting, fog activated fungal growth on the litter of the Namib dune grass Stipagrostis sabulicola, with implications for desert food webs and biogeochemical cycling. Thus, from the tallest forest trees to the smallest desert rocks, in the absence of rain, fog may well act to sustain "normal" tree (microbial) functions at different points in the landscape.

By intercepting and routing water to soils during dry periods, canopy dominants-or rock surfaces-may well facilitate understory or nearby plant growth (Warren-Rhodes and others 2013; Baguskas and others 2016). Using hydrogen isotopes to trace water inputs and use in a California redwood forest, Dawson (1998) estimated that 6$100 \%$ of the water used by herbs and shrubs growing below Sequoia sempervirens was obtained through fog drip inputs to the forest floor. Regeneration in rain forest islands has also been linked to spatial patterns of fog input (Rigg and others 2002; Del-Val and others 2006; Stanton and others 2014). In coastal Chile, seedling and sapling abundance were significantly greater at windward fog-receiving than leeward edges, whereas tree mortality exhibited the opposite pattern, suggesting an advancing regeneration front in the direction of fog input (Del-Val and others 2006). The potential for saplings to benefit more from dry-season, fog-mediated improvements in water status than adult trees may explain such patterns (Baguskas and others 2016). Whether through changes in nutrient or carbon cycling it is indeed plausible that fog influences species' distributions, but beyond the role of changing water dynamics, it is unclear how. These studies highlight the need for closer examination of plant-plant interactions and functions occurring below trees, plants, and rocks in fog-enshrouded ecosystems, and raise new questions about fog's role in biogeochemical cycling.

\section{Elemental Interactions}

It is well established that fog can deliver essential limiting nutrients, such as $\mathrm{N}$ and $\mathrm{P}$ (for example, Weathers and other 2000, Nyaga and others 2015; Vandecar and others 2015), as well as pollutants (for example, Masson and others 2015) to soils and vegetation. The effects of fog pollutant inputs on plant anatomy and physiology were demonstrated 
beginning in the mid- to late twentieth century. Misting experiments showed that acid fog had the potential to directly alter leaf epicuticular wax structure and chemistry (Percy and others 1992) and to indirectly influence leaf nutrient status via foliar leaching of cations and other plant compounds (for example, Scherbatskoy and Klein 1983; Figure 1). Foliar nutrient leaching (for example, membrane-associated $\mathrm{Ca}$ ) has since been linked to decreased stomatal conductance (Borer and others 2005) and leaf number (Shigihara and others 2008) and increased leaf abscission (Shigihara and others 2008) in seedling experiments, suggesting the potential for associated positive or negative effects on $\mathrm{CO}_{2}$ assimilation and/or decomposition.

In contrast to the early focus on fog pollutants, only relatively recently have tracer studies demonstrated that nutrients (for example, glycine, $\mathrm{NO}_{3}{ }^{-}, \mathrm{NH}_{4}{ }^{+}$) deposited to fog-wetted canopies can be absorbed directly through plant foliage (Lai and others 2007; Nyaga and others 2015)-enhancing leaf-level photosynthesis (Templer and others 2015) - and transported to the roots (Lai and others 2007). Foliar nutrient uptake has also been inferred through correlative measures. For example, in a study of atmospheric bromeliads growing on coastal desert sands, positive correlations between fog $\mathrm{N}$ input and plant $\mathrm{N}$ content and fog $\mathrm{P}$ input and plant growth rate were detected (González and others 2011). Although the relative importance of direct foliar vs. indirect root fog-borne nutrient uptake remains elusive (Templer and others 2015), evidence from several fog-affected ecosystems now indicates that the supply of limiting nutrients in fog waters can sustain plant growth in resource-poor environments. Fog can also be an important vector of carbon-organic and elemental (Collett and others 2008)—-to ecosystems, although the effects of these added carbon inputs to ecosystem function remain unknown.

\section{Light Scattering and Absorption}

The influence of fog on the light environment has implications for critical ecosystem processes, including primary productivity, water cycling, and nitrogen deposition (Figure 1). Fog reduces the amount of total and photosynthetically active radiation received by plants (Letts and Mulligan 2005; Brant and others Unpublished Data), but the overall effects on carbon gain appear to be speciesor forest-dependent (Johnson and Smith 2008). For many woody species, these lower light intensities are often at or below the light compensation point for photosynthesis resulting in net $\mathrm{C}$ loss. However, a growing literature suggests that greater proportions of diffuse light under foggy skies can actually enhance understory as well as canopyscale photosynthesis (Johnson and Smith 2006; Still and others 2009). The greater penetration and spatial homogenization of diffuse light in forest canopies, for example, is likely to increase the exposure of shade leaves to radiation that would otherwise be unavailable. Further fog-induced changes in the quality of incident light have been reported (Reinhardt and others 2010) although effects on photosynthesis remain undetermined. Through decreases in solar radiation inputs, vapor pressure deficit, and ambient air temperatures, fog may also serve to reduce drought stress among plants and microbial populations (Fischer and others 2009; Carbone and others 2013). Through such microenvironmental changes, fog events have been found to reduce tree transpiration rates by up to 30-fold (Ritter and others 2009) and in turn water-use efficiency (Johnson and Smith 2008). Finally, upon exposure to sunlight, organic N compounds dissolved in fog droplets may be converted to inorganic $\mathrm{N}$ species $\left(\mathrm{NO}_{3}{ }^{-}, \mathrm{NH}_{4}{ }^{+}, \mathrm{NO}_{\mathrm{x}}\right)$, increasing bioavailable $\mathrm{N}$ for deposition to ecosystems (Zhang and Anastasio 2003). The latter study highlights some of the hidden interactions among water, nutrient availability, and light that are likely to affect ecosystem processes in fog-influenced ecosystems.

\section{Frontiers in fog Research}

Fog as a vector and connector: Fog represents a critical nexus among atmosphere, biosphere, and hydrosphere, linking atmospheric, terrestrial, and marine ecosystems. Coastal fog is formed over the ocean as a result of temperature differences between air and water and then advected inland. As such, there are many "mist" opportunities to examine cross-system or boundary (Cadenasso and others 2003) influences on ecosystem function. How does ocean biogeochemistry, and productivity, in particular, influence the nature of nearcoastal, terrestrial fog subsidies, for example? Fog water has been shown to carry not only sea salt, but also nutrients (Weathers and others 2000), pollutants (Weiss-Penzias and others 2012), and microbes (Evans and others 2018) originating from biotic processing in marine systems, and delivered to adjacent terrestrial ecosystems. Thus, in some cases, the ocean may be "feeding" the forest (sensu Weathers and others 2000). In other cases, the ocean is sharing pollutants with adjacent terrestrial 
ecosystems via fog as a vector (Reyes-Rodríguez and others 2009). In another recent example, the ocean is the source of microbes and pathogens whereby fog not only moves biological materials from ocean to air to land (Dueker and others 2011, 2012) in a direction that we are unused to considering but does so while possibly providing suitable habitat for microbes to prosper (Evans and others 2018)—in essence, "seeding" terrestrial ecosystems. The fog system is a dynamic connector across earth system boundaries; many mist connections have yet to be explored, however.

The controls and consequences of atmospheric microbial dynamics (aerobiology) represent one outstanding, fundamental knowledge gap in understanding these cross-system dynamics. Environmentally beneficial and pathogenic microbes can travel short to long distances adhered to particles in tiny fog droplets before eventual deposition to terrestrial ecosystems; an emerging literature suggests that microorganisms differ in how they are transported and deposited (Reche and others 2018). Bacteria are often the dominant microorganism in fog water (Hu and others 2018) and there is evidence that fog waters protect and sustain bacterial communities from harsh conditions following aerosolization by providing water and nutrients and via increased settling rates (Dueker and others 2012; Amato and others 2017).

Even as we begin to understand and quantify the relative importance of fog subsidies and fluxes to ecological systems, and the details of how fog affects ecosystem processes, global change is altering the nature of fog itself and the ecosystems that have evolved to capture this ephemeral resource. Daily and seasonal timing of fog events, as well as fog immersion time (that is, duration and frequency), governs the volume of fog water inputs to ecosystems; they also affect the chemistry and biology of fog. Yet there are only a handful of examples where spatial and temporal data for fog frequency and immersion are available; it is a crucial data gap that may be filled, in part, using remote sensing technology (for example, Cermak 2012). Changes in frequency and distribution of fog for some regions of the world have been inferred using general circulation models, meteorological data, climate proxies, and observations of cloud ceiling height. In fact, there are now several regions where fog frequency is on the decline (LaDochy 2005; Vautard and others 2009; Johnstone and Dawson 2010; Baldocchi and Waller 2014; Williams and others 2015; Gautam and Singh 2018), with potentially important effects on agroecosystems and forests. A comparison of clear-sky and foggy conditions showed that fog contributes to decreased canopy-scale water loss and canopy-level photosynthesis, but an overall increase in wateruse efficiency, on strawberry farms (Baguskas and others 2018). In another study conducted in a major fruit and nut growing region, foggy days had lower mean solar radiation load, lower maximum, and lower mean temperatures than clear days contributing to the winter chill required by trees for high productivity (Baldocchi and Waller 2014). Therefore, declining fog could affect crop yields by reducing winter chill and/or plant-water-use efficiency. In regions where fog events buffer native ecosystems against periodic drought, presumably fog reductions will result in increased evapotranspiration rates and vulnerability to drought stress (Johnstone and Dawson 2010). Of crucial importance, therefore, is quantification of immersion time, distribution, and frequency of fog for fogdominated systems, as well as their changes over time.

Whether the influence is direct or indirect, fog has the potential to control ecosystem function in fog-enshrouded ecosystems. Fog can be a resource, pollutant, and master driver variable in the fixation of carbon, decomposition, hydrological fluxes and dynamics, and overall biogeochemistry of terrestrial systems. Fog is a vector and connector for the biotic and abiotic movement and dynamics across major earth systems. Although fog-dominated systems may cover a small proportion of the Earth's surface (crude estimates range from $<10-30 \%$ of the Earth's surface), they are located in coastal and montane regions that support high biodiversity, as well an increasing human population, and/or are surrounded by highly polluted aquatic and atmospheric systems: They are hot spots of Earth ecosystem dynamics, but much research remains to be done to reveal the ecosystem consequences of changing fog frequency and distribution. Further, because changes-differences, in fact-in air temperature in large part control fog formation, climate change scenarios which include warming will have an important role in altering fog occurrence on a global scale. Finally, understanding the feedback dynamics among and between marine, terrestrial, and fog (atmospheric) systems are crucial for being able to predict and unravel cross-system, fog dynamics (Figure 1). Remote sensing tools combined with in situ ecosystem process measurements, and models, made across fog-enshrouded ecosystems are near-term research needs and frontiers. 


\section{ACKNOWLEDGMENTS}

We thank Amanda M. Lindsey and Bethel G. Steele for assistance with figures, our many collaborators and colleagues in fog science with whom we have shared conversations, ideas, and a passion for exploring fog system dynamics, and the anonymous reviews of peers and editors who enhanced the manuscript.

\section{OPEN ACCESS}

This article is distributed under the terms of the Creative Commons Attribution 4.0 International License (http://creativecommons.org/licenses/by/4 $.0 /$ ), which permits unrestricted use, distribution, and reproduction in any medium, provided you give appropriate credit to the original author(s) and the source, provide a link to the Creative Commons license, and indicate if changes were made.

\section{REFERENCES}

Aikawa M, Hiraki T, Tamaki M. 2006. Comparative field study on precipitation, throughfall, stemflow, fog water, and atmospheric aerosol and gases at urban and rural sites in Japan. Science of the Total Environment 366:275-85.

Aleksic N, Roy K, Sistla G, Dukett J, Houck N, Casson P. 2009. Analysis of cloud and precipitation chemistry at Whiteface Mountain, NY. Atmospheric Environment 43:2709-16.

Alvarado-Barrientos MS, Holwerda F, Asbjornsen H, Dawson TE, Bruijnzeel LA. 2014. Suppression of transpiration due to cloud immersion in a seasonally dry Mexican weeping pine plantation. Agricultural and Forest Meteorology 186:12-25.

Amato P, Joly M, Besaury L, Oudart A, Taib N, Moné AI, Deguillaume L, Delort A-M, Debroas D. 2017. Active microorganisms thrive among extremely diverse communities in cloud water. PLoS ONE 12:e182869.

Anderson JB, Baumgardner RE, Mohnen VA, Bowser JJ. 1999. Cloud chemistry in the eastern United States, as sampled from three high-elevation sites along the Appalachian Mountains. Atmospheric Environment 33:5105-14.

Asbury CE, McDowell WH, Trinidad-Pizarro R, Berrios S. 1994. Solute deposition from cloud water to the canopy of a Puerto Rican montane forest. Atmospheric Environment 28:1773-80.

Baguskas SA, Clemesha RES, Loik ME. 2018. Coastal low cloudiness and fog enhance crop water use efficiency in a California agricultural system. Agricultural and Forest Meteorology 252:109-20.

Baguskas SA, King JY, Fischer DT, D'Antonio CM, Still CJ. 2017. Impact of fog drip versus fog immersion on the physiology of Bishop pine saplings. Functional Plant Biology. 2:339-50.

Baguskas SA, Peterson SH, Bookhagen B, Still CJ. 2014. Evaluating spatial patterns of drought-induced tree mortality in a coastal California pine forest. Forest Ecology and Management 315:43-53.

Baguskas SA, Still CJ, Fischer DT, D'Antonio CM, King JY. 2016. Coastal fog during summer drought improves the water status of sapling trees more than adult trees in a California pine forest. Oecologia 181:137-48.
Baldocchi D, Waller E. 2014. Winter fog is decreasing in the fruit growing region of the Central Valley of California. Geophysical Research Letters 41:3251-6. https://doi.org/10.1002/201 4GL060018.

Bator A, Collett JL Jr. 1997. Cloud chemistry varies with drop size. Journal of Geophysical Research: Atmospheres 102:28.

Baumgardner RE Jr, Isil SS, Lavery TF, Rogers CM, Mohnen VA. 2003. Estimates of cloud water deposition at mountain acid deposition program sites in the Appalachian Mountains. Journal of the Air \& Waste Management Association 53:291308.

Baynton HW. 1968. The ecology of an elfin forest in Puerto Rico, 2. Microclimate of Pico del Oeste. Journal of the Arnold Arboretum 49:419-30.

Berry ZC, Emery NC, Gotch SG, Goldsmith GR. 2018. Foliar water uptake: processes, pathways and integration into plant water budgets. Plant Cell and Environment . https://doi.org/ 10.1111 /pce.13439.

Berry ZC, Hughes NM, Smith WK. 2014. Cloud immersion: an important water source for spruce and fir saplings in the southern Appalachian Mountains. Oecologia 174:319-26.

Borer CH, Schaberg PG, DeHayes DH. 2005. Acidic mist reduces foliar membrane-associated calcium and impairs stomatal responsiveness in red spruce. Tree Physiology 25:673-80.

Bruijnzeel LA, Proctor J. 1995. Hydrology and biogeochemistry of tropical montane cloud forests: what do we really know? In: Hamilton LS, Juvik JO, Scatena FN, Eds. tropical montane cloud forests, Vol. 110. New York: Springer-Verlag. p 38-78.

Burgess SSO, Dawson TE. 2004. The contribution of fog to the water relations of Sequoia sempervirens (D.Don): foliar uptake and prevention of dehydration. Plant, Cell and Environment 27:1023-34.

Cadenasso ML, Pickett STA, Weathers KC, Jones CG. 2003. A framework for a theory of boundaries. BioScience 53:750-8.

Carbone MS, Still CJ, Ambrose AR, Dawson TE, Williams AP, Boot CM, Schaeffer SM, Schimel JP. 2011. Seasonal and episodic moisture controls on plant and microbial contributions to soil respiration. Oecologia 167:265-78.

Carbone MS, Williams AP, Ambrose AR, Boot CM, Bradley ES, Dawson TE, Schaeffer SM, Schimel JP, Still CJ. 2013. Cloud shading and fog drip influence the metabolism of a coastal pine ecosystem. Global Change Biology 19:484-97.

Carrillo JH, Hastings MG, Sigman DM, Huebert BJ. 2002. Atmospheric deposition of inorganic and organic nitrogen and base cations in Hawaii. Global Biogeochemical Cycles. http s://doi.org/10.1029/2002gb001892.

Cavelier J, Goldstein G. 1989. Mist and fog interception in elfin cloud forests in Colombia and Venezuela. Journal of Tropical Ecology 5:309-22.

Cermak J. 2012. Low clouds and fog along the southwester African coast-satellite-based retrievals and spatial patterns. Atmospheric Research 116:15-21.

Chang S-C, Tseng K-H, Hsia Y-J, Wang C-P, Wu J-T. 2008. Soil respiration in a subtropical montane cloud forest in Taiwan. Agricultural and Forest Meteorology 148:788-98.

Chung M, Dufour A, Pluche R, Thompson S. 2017. How much does dry-season fog matter? Quantifying fog contributions to water balance in a coastal California watershed. Hydrological Processes 31:3948-61.

Collett JL Jr, Herckes P, Youngster S, Lee T. 2008. Processing of atmospheric organic matter by California radiation fogs. Atmospheric Research 87:232-41. 
Collett JL Jr, Hoag KJ, Sherman DE, Bator A, Richards LW. 1998. Spatial and temporal variations in San Joaquin Valley fog chemistry. Atmospheric Environment 33:129-40.

Corbin J, Thomsen M, Dawson T, D'Antonio C. 2005. Summer water use by California coastal prairie grasses: fog, drought, and community composition. Oecologia 145:511-21.

Dawson TE. 1998. Fog in the California redwood forest: ecosystem inputs and use by plants. Oecologia 117:476-85.

Dawson TE, Goldsmith GR. 2018. The value of wet leaves. New Phytologist 219:1156-69. https://doi.org/10.1111/nph.15307.

del Río C, Garcia J-L, Osses P, Zanetta N, Lambert F, Rivera D, Siegmund A, Wolf N, Cereceda P, Larraín H. 2018. ENSO influence on coastal fog-water yield in the Atacama Desert, Chile. Aerosol and Air Quality Research 18:127-44.

Del-Val E, Armesto JJ, Barbosa O, Christie DA, Gutiérrez AG, Jones CG, Marquet PA, Weathers KC. 2006. Rain forest islands in the Chilean semiarid region: Fog-dependency, ecosystem persistence and tree regeneration. Ecosystems 9:598-608.

Desyaterik Y, Sun Y, Shen X, Lee T, Wang X, Wang T, Collett JL. 2013. Speciation of "brown" carbon in cloud water impacted by agricultural biomass burning in eastern China. Journal of Geophysical Research: Atmospheres 118:7389-99.

Dollard GJ, Unsworth MH. 1983. Field measurements of turbulent fluxes of wind-driven fog drops to a grass surface. Atmospheric Environment 17:775-80.

Dollard GJ, Unsworth MH, Harve MJ. 1983. Pollutant transfer in upland regions by occult precipitation. Nature 302:241-3.

Dueker ME, O'Mullan GD, Weathers KC, Juhl AR, Uriarte M. 2012. Coupling of fog and marine microbial content in the near-shore coastal environment. Biogeosciences 9:803-13.

Dueker ME, Weathers KC, O'Mullan GD, Juhl AR, Uriarte M. 2011. Environmental controls on coastal coarse aerosols: implications for microbial content and deposition in the nearshore environment. Environmental Science and Technology 45:3386-92.

Eller CB, Lima AL, Oliveira RS. 2013. Foliar uptake of fog water and transport belowground alleviates drought effects in the cloud forest tree species, Drimys brasiliensis (Winteraceae). New Phytologist 199:151-62.

Emery NC. 2016. Foliar uptake of fog in coastal California shrub species. Oecologia 182:731-42.

Evans S, Dueker ME, Logan R, Weathers KC. 2018. The biology of fog. Science of the Total Environment 47:1547-56.

Ewing HA, Weathers KC, Templer PH, Dawson TE, Firestone MK, Elliott AM, Boukili VKS. 2009. Fog water and ecosystem function: heterogeneity in a California redwood forest. Ecosystems 12:417-33.

Fischer DT, Still CJ, Ebert CM, Baguskas SA, Williams AP. 2016. Fog drip maintains dry season ecological function in a California coastal pine forest. Ecosphere 7:Article e01364.

Fischer DT, Still CJ, Williams AP. 2009. Significance of summer fog and overcast for drought stress and ecological functioning of coastal California endemic plant species. Journal of Biogeography 36:783-99.

Fuzzi S, Orsi G, Mariotti M. 1985. Wet deposition due to fog in the Po Valley, Italy. Journal of Atmospheric Chemistry 3:28996.

Gautam R, Singh MK. 2018. Urban heat island over Delhi punches holes in widespread fog in the Indo-Gangetic Plains. Geophysical Research Letters . https://doi.org/10.1002/2017 GL076794.
Gioda A, Mayol-Bracero OL, Scatena FN, Weathers KC, Mateus VL, McDowell WH. 2013. Chemical constituents in clouds and rainwater in the Puerto Rican rainforest: Potential sources and seasonal drivers. Atmospheric Environment 68:208-20.

Gioda A, Reyes-Rodríguez GJ, Santos-Figueroa G, Collett JL Jr, Decesari S, da Ramos MCKV, Bezerra Netto HJC, de Aquino Neto FR, Mayol-Bracero OL. 2011. Speciation of water-soluble inorganic, organic, and total nitrogen in a background marine environment: Cloud water, rainwater, and aerosol particles. Journal of Geophysical Research . https://doi.org/10. 1029/2010jd015010.

Goldsmith GR, Matzke NJ, Dawson TE. 2013. The incidence and implications of clouds for cloud forest plant water relations. Ecology Letters 16:307-14.

González AL, Fariña JM, Pinto R, Pérez C, Weathers KC, Armesto JJ, Marquet PA. 2011. Bromeliad growth and stoichiometry: responses to atmospheric nutrient supply in fogdependent ecosystems of the hyper-arid Atacama Desert, Chile. Oecologia 167:835-45.

Gotsch SG, Asbjornsen H, Holwerda F, Goldsmith GR, Weintraub AE, Dawson TE. 2014. Foggy days and dry nights determine crown-level water balance in a seasonal tropical montane cloud forest. Plant, Cell and Environment 37:26172.

Grubb PJ, Whitmore TC. 1966. A comparison of montane and lowland rain forest in Ecuador: II. The climate and its effects on the distribution and physiognomy of the forests. Journal of Ecology 54:303-33.

Gu L, Baldocchi DD, Wofsy SC, Munger JW, Michalsky JJ, Urbanski SP, Boden TA. 2003. Response of a deciduous forest to the Mount Pinatubo eruption: Enhanced photosynthesis. Science. 299:2035-8.

Gutiérrez ÁG, Barbosa O, Christie DA, del-Val EK, Ewing HA, Jones CG, Marquet PA, Weathers KC, Armesto J. 2008. Regeneration patterns and persistence of the fog-dependent Fray Jorge Forest in semiarid Chile during the past two centuries. Global Change Biology 14:161-76.

Heath JA, Huebert BJ. 1999. Cloudwater deposition as a source of fixed nitrogen in a Hawaiian montane forest. Biogeochemistry 44:119-34.

Hildebrandt A, Al Aufi M, Amerjeed M, Shammas M, Eltahir EAB. 2007. Ecohydrology of a seasonal cloud forest in Dhofar: 1. Field experiment. Water Resources Research 43:1. https://d oi.org/10.1029/2006wr005261.

Hill AJ, Dawson TE, Shelef O, Rachmilevitch S. 2015. The role of dew for Negev Desert plants. Oecologia 178:317-27.

Hu W, Niu H, Murata K, Wu Z, Hu M, Kojima T, Zhang D. 2018. Bacteria in atmospheric waters: Detection, characteristics and implications. Atmospheric Environment 179:201-21.

Ingraham NL, Matthews RA. 1988. Fog drip as a source of groundwater recharge in northern Kenya. Water Resources Research 24:1406-10.

Ingraham NL, Matthews RA. 1995. The importance of fog-drip water to vegetation: Point Reyes Peninsula, California. Journal of Hydrology 164:269-85.

Jacobson K, van Diepeningen A, Evans S, Fritts R, Gemmel P, Marsho C, Seely M, Wenndt A, Yang X, Jacobson P. 2015. Non-rainfall moisture activates fungal decomposition of surface litter in the Namib Sand Sea. PLoS One 10:e0126977.

Johnson DM, Smith WK. 2006. Low clouds and cloud immersion enhance photosynthesis in understory species of a 
southern Appalachian spruce-fir forest (USA). American Journal of Botany 93:1625-32.

Johnson DM, Smith WK. 2008. Cloud immersion alters microclimate, photosynthesis and water relations in Rhododendron catawbiense and Abies fraseri seedlings in the southern Appalachian Mountains, USA. Tree Physiology 28:385-92.

Johnstone JA, Dawson TE. 2010. Climatic context and ecological implications of summer fog decline in the coast redwood region. Proceedings of the National Academy of Sciences 107:4533-8.

Kerfoot O. 1968. Mist precipitation on vegetation. Forestry Abstracts 29:8-20.

Klemm O, Chang SC, Hsia YJ. 2006. Energy fluxes at a subtropical mountain cloud forest. Forest Ecology and Management 224:5-10.

Lacaux JP, Loemba-Ndembi J, Lefeivre B, Cros B, Delmas R. 1992. Biogenic emissions and biomass burning influences on the chemistry of the fogwater and stratiform precipitations in the African equatorial forest. Atmospheric Environment: Part A General Topics 26A:541-51.

LaDochy S. 2005. The disappearance of dense fog in Los Angeles: Another urban impact? Physical Geography 26:177-91.

Lai I-L, Schroeder WH, Wu J-T, Kuo-Huang L-L, Mohl C, Chou C-H. 2007. Can fog contribute to the nutrition of Chamaecyparis obtusa var. formosana? Uptake of a fog solute tracer into foliage and transport to roots. Tree Physiology 27:1001-9.

Lawson ST, Scherbatskoy TD, Malcolm EG, Keeler GJ. 2003. Cloud water and throughfall deposition of mercury and trace elements in a high elevation spruce-fir forest at Mt. Mansfield. Vermont. Journal of Environmental Monitoring 5:57883.

Lehnert LW, Thies B, Trachte K, Achilles S, Osses P, Baumann K, Schmidt J, Samolov E, Jung P, Leinweber P. 2018. A case study on fog/low stratus occurrence at Las Lomitas, Atacama Desert (Chile) as a water source for biological soil crusts. Aerosol and Air Quality Research 18:254-69.

Letts MG, Mulligan M. 2005. The impact of light quality and leaf wetness on photosynthesis in north-west Andean tropical montane cloud forest. Journal of Tropical Ecology 21:549-57.

Li B, Wang L, Kaseke KF, Vogt R, Li L, Seely MK. 2018. The impact of fog on soil moisture dynamics in the Namib Desert. Advances in Water Resources 113:23-9.

Limm EB, Simonin KA, Bothman AG, Dawson TE. 2009. Foliar water uptake: a common water acquisition strategy for plants of the redwood forest. Oecologia 161:449-59.

Liu WJ, Zhang YP, Li HM, Meng FR, Liu YH, Wang C-M. 2005. Fog- and rainwater chemistry in the tropical seasonal rain forest of Xishuangbanna, southwest China. Water, Air, and Soil Pollution 167:295-309.

Lovett GM, Reiners WA, Olson RK. 1982. Cloud droplet deposition in subalpine balsam fir forests: hydrological and chemical inputs. Science 218:1303-4.

Marloth R. 1903. Results of experiments on Table Mountain for ascertaining the amount of moisture deposited from the south-east clouds. Transactions of the South African Philosophical Society 14:403-8.

Marloth R. 1905. Results of further experiments on Table Mountain for ascertaining the amount of moisture deposited from the southeast clouds. Transactions of the South African Philosophical Society 16:97-105.

Masson O, de Vismes Ott A, Bourcier L, Paulat P, Ribeiro M, Pichon J-M, Sellegri K, Gurriaran R. 2015. Change of radioactive cesium $\left({ }^{137} \mathrm{Cs}\right.$ and $\left.{ }^{134} \mathrm{Cs}\right)$ content in cloud water at an elevated site in France, before and after the Fukushima nuclear accident: Comparison with radioactivity in rainwater and in aerosol particles. Atmospheric Research 151:45-51.

Matimati I, Musil CF, Raitt L, February E. 2012. Non rainfall moisture interception by dwarf succulents and their relative abundance in an inland arid South African ecosystem. Ecohydrology 6:818-25.

Means TH. 1927. Fog precipitated by trees. Science 66:402-3.

Munger JW, Jacob DJ, Waldman JM, Hoffmann MR. 1983. Fogwater chemistry in an urban atmosphere. Journal of Geophysical Research 88:5109-21.

Nadkarni NM, Sumera MM. 2004. Old-growth forest canopy structure and its relationship to throughfall interception. Forest Science 50:290-8.

Nørgaard T, Dacke M. 2010. Fog-basking behviour and water collection efficiency in Namib desert darkling beetles. Frontiers in Zoology 7:23.

Nyaga JM, Neff JC, Cramer MD. 2015. The contribution of occult precipitation to nutrient deposition on the west coast of South Africa. PLoS One 10:e0126225.

Oberlander GT. 1956. Summer fog precipitation on the San Francisco Peninsula. Ecology 37:851-2.

Odum HT, Pigeon RF. 1970. A tropical rain forest: a study of irradiation and ecology at El Verde, Puerto Rico. Washington DC, USA: U.S. Atomic Energy Commission, Division of Technical Information.

Parker AR, Lawrence CR. 2001. Water capture by a desert beetle. Nature 414:33-4.

Parsons JJ. 1960. 'Fog drip' from coastal stratus, with special reference to California. Weather 15:58-62.

Percy KE, Jensen KF, McQuattie CJ. 1992. Effects of ozone and acidic fog on red spruce needle epicuticular wax production, chemical composition, cuticular membrane ultrastructure and needle wettability. New Phytologist 122:71-80.

Poca M, Cingolani AM, Gurvich DE, Palmieri VS, Bertone G. 2018. Water storage dynamics across different types of vegetated patches in rocky highlands of central Argentina. Ecohydrology 11:e1981.

Ponette-González AG, Ewing HA, Weathers KC. 2016. Interactions between precipitation and vegetation canopies. In: Johnson EA, Martin YE, Eds. A Biogeoscience Approach to Ecosystems. Cambridge: Cambridge University Press. p 21553.

Ponette-González AG, Marín-Spiotta E, Brauman KA, Farley KA, Weathers KC, Young KR. 2014. Hydrologic connectivity in the high-elevation tropics: heterogeneous responses to land change. BioScience 64:92-104.

Ponette-González AG, Weathers KC, Curran LM. 2010a. Tropical land-cover change alters biogeochemical inputs to ecosystems in a Mexican montane landscape. Ecological Applications 20:1820-37.

Ponette-González AG, Weathers KC, Curran LM. 2010b. Water inputs across a tropical montane landscape in Veracruz, Mexico: synergistic effects of land cover, rain and fog seasonality, and interannual precipitation variability. Global Change Biology 16:946-63.

Prada S, Menezes de Sequeira M, Figueira C, da Silva MO. 2009. Fog precipitation and rainfall interception in the natural forests of Madeira Island (Portugal). Agricultural and Forest Meteorology 149:1179-87. 
Reche I, D'Orta G, Mladenov N, Winget DM, Suttle CA. 2018. Deposition rates of viruses and bacteria above the atmospheric boundary layer. ISME Journal 12:1154-62.

Reinhardt K, Smith WK, Carter GA. 2010. Clouds and cloud immersion alter photosynthetic light quality in a temperate mountain cloud forest. Botany 88:462-70.

Reyes-Rodríguez GJ, Gioda A, Mayol-Bracero OL, Collett J Jr. 2009. Organic carbon, total nitrogen, and water-soluble ions in clouds from a tropical montane cloud forest in Puerto Rico. Atmospheric Environment 43:4171-7.

Rigg LS, Enright NJ, Perry GLW, Miller BP. 2002. The role of cloud combing and shading by isolated trees in the succession from maquis to rain forest in New Caledonia. Biotropica 34:199-210.

Ritter A, Regalado CM, Aschan G. 2009. Fog reduces transpiration in tree species of the Canarian relict heath-laurel cloud forest (Garajonay National Park, Spain). Tree Physiology 29:517-28.

Santiago LS, Dawson TE. 2014. Light use efficiency of California redwood forest understory plants along a moisture gradient. Oecologia 174:351-63.

Schemenauer RS. 1986. Acidic deposition to forests: the 1985 chemistry of high elevation fog (CHEF) project. AtmosphereOcean 24:303-28.

Scherbatskoy T, Klein RM. 1983. Response of spruce and birch foliage to leaching by acidic mists. Journal of Environmental Quality 12:189-95.

Schlesinger WH, Reiners WA. 1974. Deposition of water and cations on artificial foliar collectors in fir krummholz of New England mountains. Ecology 55:378-86.

Seely MK. 1979. Irregular fog as a water source for desert dune beetles. Oecologia 42:213-27.

Seely M, Henschel JR, Hamilton WJIII. 2005. Long-term data show behavioural fog collection adaptations determine Namib Desert beetle abundance. South African Journal of Science. 101:570-2.

Shigihara A, Matsumoto K, Sakurai N, Igawa M. 2008. Growth and physiological responses of beech seedlings to long-term exposure of acid fog. Science of the Total Environment 391:124-31.

Simonin KA, Santiago LS, Dawson TE. 2009. Fog interception by Sequoia sempervirens (D. Don) crowns decouples physiology from soil water deficit. Plant, Cell and Environment 32:88292.

Stanton DE, Armesto JJ, Hedin LO. 2014. Ecosystem properties self-organize in response to a directional fog-vegetation interaction. Ecology 95:1203-12.

Still CJ, Riley WJ, Biraud SC, Noone DC, Buenning NH, Randerson JT, Torn MS, Welker J, White JWC, Vachon R, Farquhar GD, Berry JA. 2009. Influence of clouds and diffuse radiation on ecosystem-atmosphere $\mathrm{CO}_{2}$ and $\mathrm{CO}^{18} \mathrm{O}$ exchanges. Journal of Geophysical Research 114:1. https://doi. org/10.1029/2007jg000675.

Templer PH, Weathers KC, Ewing HA, Dawson TE, Mambelli S, Lindsey AM, Webb J, Boukili VK, Firestone MK. 2015. Fog as a source of nitrogen for redwood trees: evidence from fluxes and stable isotopes. Journal of Ecology 103:1397-407.

Thalmann E, Burkard R, Wrzesinsky T, Eugster W, Klemm O. 2002. Ion fluxes from fog and rain to an agricultural and a forest ecosystem in Europe. Atmospheric Research 64:147-58.
Thornes JE, Metherell G. 2003. Monet's 'London Series' and the cultural climate of London at the turn of the Twentieth Century. Weather, Climate, Culture:141-60.

Vandecar KL, Runyan CW, D'Odorico P, Lawrence D, Schmook B, Das R. 2015. Phosphorus input through fog deposition in a dry tropical forest. Journal of Geophysical Research: Biogeosciences 120:2493-504. https://doi.org/10.1002/2015J G002942.

Vautard R, Yiou P, van Oldenborgh GJ. 2009. Decline of fog, mist and haze in Europe over the past 30 years. Nature Geoscience 2:115-19.

Waldman JM, Munger JW, Jacob DJ, Flagan RC, Morgan JJ, Hoffman MR. 1982. Chemical composition of acid fog. Science 218:677-80.

Warren-Rhodes KA, McKay CP, Boyle LN, Wing MR, Kiekebusch EM, Cowan DA, Stomeo F, Pointing SB, Kaseke KF, Eckardt F, Henschel JR, Anisfeld A, Seely M, Rhodes KL. 2013. Physical ecology of hypolithic communities in the central Namib Desert: the role of fog, rain, rock habitat, and light. Journal of Geophysical Research: Biogeosciences 118:1451-60. https://doi.org/10.1002/jgrg.20117.

Weathers KC, Likens GE. 1997. Clouds in southern Chile: An important source of nitrogen to nitrogen-limited ecosystems? Environmental Science and Technology 31:210-13.

Weathers KC, Likens GE, Bormann FH, Bicknell SH, Bormann BT, Daube BC Jr, Eaton JS, Galloway JN, Keene WC, Kimball KD, McDowell WH, Siccama TG, Smiley D, Tarrant RA. 1988. Cloudwater chemistry from ten sites in North America. Environmental Science and Technology 22:1018-26.

Weathers KC, Likens GE, Bormann FH, Eaton JS, Bowden WB, Andersen JL, Cass DA, Galloway JN, Keene WC, Kimball KD, Huth P, Smiley D. 1986. A regional acidic cloud/fog water event in the eastern United States. Nature 319:657-8.

Weathers KC, Lovett GM. 1998. Acid deposition research and ecosystem science: synergistic successes. In: Pace ML, Groffman PM, Eds. Successes, Limitations, and Frontiers in Ecosystem Science. New York: Springer. p 195-219.

Weathers KC, Lovett GM, Likens GE. 1992. The influence of a forest edge on cloud deposition. In: Schwartz SE, Slinn WGN, Eds. Precipitation scavenging and atmosphere-surface exchange, Vol. 3. Washington: Hemisphere Publishing. p 141523.

Weathers KC, Lovett GM, Likens GE. 1995. Cloud deposition to a spruce forest edge. Atmospheric Environment 29:665-72.

Weathers KC, Lovett GM, Likens GE, Caraco NFM. 2000. Cloudwater inputs of nitrogen to forest ecosystems in southern Chile: Forms, fluxes, and sources. Ecosystems 3:590-5.

Weathers KC, Simkin SM, Lovett GM, Lindberg SE. 2006. Empirical modeling of atmospheric deposition in mountainous landscapes. Ecological Applications 16:1590-607.

Weiss-Penzias P, Coale K, Heim W, Fernandez D, Oliphant A, Dodge C, Hoskins D, Farlin J, Moranville R, Olson A. 2016. Total- and monomethyl-mercury and major ions in coastal California fog water: Results from two years of sampling on land and at sea. Elementa: Science of the Anthropocene. $\mathrm{h}$ ttps://doi.org/10.12952/journal.elementa.000101.

Weiss-Penzias PS, Ortiz C Jr, Acosta RP, Heim W, Ryan JP, Fernandez D, Collett JL Jr, Flegal AR. 2012. Total and monomethyl mercury in fog water from the central California coast. Geophysical Research Letters . https://doi.org/10.1029/ $201 \operatorname{lgl} 050324$ 
Williams AP, Schwartz RE, Iacobellis S, Seager R, Cook BI, Still CJ, Husak G, Michaelsen J. 2015. Urbanization causes increased cloud base height and decreased fog in coastal Southern California. Geophysical Research Letters 42:152736. https://doi.org/10.1002/2015GL063266.

Williams AP, Still CJ, Fischer DT, Leavitt SW. 2008. The influence of summertime fog and overcast clouds on the growth of a coastal Californian pine: a tree-ring study. Oecologia 156:601-11.
Yan X, Zhou M, Dong X, Zou S, Xiao H, Ma X-F. 2015. Molecular mechanisms of foliar water uptake in a desert tree. AoB Plants 7:1. https://doi.org/10.1093/aobpla/plv129.

Zhang Q, Anastasio C. 2003. Conversion of fogwater and aerosol organic nitrogen to ammonium, nitrate, and NOx during exposure to simulated sunlight and ozone. Environmental Science and Technology 37:3522-30. 